\title{
Милана Радић-Дугоњић
}

\author{
ЉУБАВ - РЕЧ, КОНЦЕПТ, МИТОЛОГЕМА \\ (на материјалу романа „Сеобе” Милоша Црњанског \\ и његовог руског превода)
}

\begin{abstract}
У раду су изнета нека кључна обележја која карактеришу љубав као реч, концепт и митологему у тексту књижевног дела и његовог превода.
\end{abstract}

Кључне речи: транслатологија, лингвокултурологија, реч, концепт, митологема.

1. Једна од предности контрастивног истраживања језичких садржаја у односу на истраживања која се одвијају у границама једног језика састоји се у томе, што појаве у анализираном језику, посматране из перспективе другог језика, постају рељефније и јасније уочљиве. Ова чињеница добро је позната свима онима који су се бавили језичком теоријом и праксом, како у сфери несродних, тако и у сфери сродних језика. Искуство нас учи да је овакав вид истраживања плодоносан у првом реду у истраживањима словенских језика, у којима су, услед велике формално-семантичке блискости, тешко уочљиве разлике, које имају суштински значај за самостално функционисање језичких система. Слична законитост може се применити и на транслатолошка проучавања језика. Познато је, наиме, да се садржаји скривени у језику књижевног дела јасније и изразитије уочавају на фону његовог превода на неки други језик. При томе не треба губити из вида да су оваквом анализом језика уметничког дела обухваћена три типа релација: релације индивидуалне језичке личности писца у односу на колективну језичку личност којој он припада, релације индивидуалне језичке личности преводиоца у односу на његову колективну језичку личност и, коначно, релације индивидуалних језичких личности писца и преводиоца.

2. Реч употребљена у функцији основног материјала од кога је саткан имагинарни свет уметничког дела, узимајући у обзир наведене релације, 
истовремено функционише и као дводимензионална, проста јединица у оквиру језичког система, али и као вишедимензионална сложена јединица - која репрезентује одређене когнитивне (концепт) и мотивационе садржаје (митологема). Одабирање јединица од којих су сачињени текстови унутар уметничког дела и њихово обједињавање у засебне смисаоне целине, представља радњу на којој се, у крилу постојећег језичког система, формира један нови систем, са својим законима и сопственим редом ствари. При томе је однос писца као индивидуалне језичке личности и колективне језичке личности којој он припада, узајамно условљен. Подсетимо се на чињеницу да су управо на материјалу врхунских дела лепе књижевности начињени речнички чланци у водећим дескриптивним речницима академијског типа у словенском свету. Уз то, материјал добијен из ових дела, заједно са фразеолошким и паремиолошким фондом, представља основне изворе за утврђивање когнитивних и културолошких обележја етноса.

3. Аналогно претходно наведеном мишљењу, према којем се појаве у језику лакше уочавају из перспективе другог језика, и превођење задатих смисаоних садржаја у форму другог језика омогућава да се кроз сучељавање слојевитих јединица двају система јасније уоче њихова засебна релевантна обележја. Јединице оригинала и превода, при томе, имају исти статус. Као што, наиме, дводимензионална реч оригинала представља само врх леденог брега, испод кога се слојевито простиру сложене когнитивно-мотивационо маркиране структуре, тако исто реч у преводу употребљена као њен дводимензионални еквивалент, представља само врх сложене засебне когнитивно-мотивационе структуре. Ове две структуpe се по правилу међусобно врло ретко подударају, чак и код блискосродних језика, тако да се с правом можемо запитати не представља ли преведено дело само више или мање успелу „варијацију на задату тему”? Или, пак, супротно томе, не представља ли успешно преведено дело, у ствари, аутохтону структуру, инспирисану оригиналом, чија је вредност сразмерна његовој кохерентности? Наведене премисе садрже следећа питања, релевантна за транслатологију: шта је то успешно преведено дело лепе књижености, шта представља његову меру вредности, и има ли непреводивих садржаја оригинала?

4. Нека од постављених питања покушаћемо да осветлимо на материјалу речи тьбав, чије ћемо смисаоне садржаје пратити у роману М. Црњанског „Сеобе” (С 1978) и његовом преводу на руски језик (П 1978).

Овим радом настављамо проучавање смисаоних садржаја речи, којима се у српском и руском језику именују емоције. ${ }^{1}$ Називи за емоције

${ }^{1}$ Видети о томе у радовима Радић-Дугоњић 2002; Радић-Дугоњић 2003. 
истовремено представљају речи, али и концепте. У литератури је примећено да поља језичких концепата-емоција по својој сложености и свеобухватности заузимају водеће место међу основним системима човека у језичкој слици света зато, што су сви остали системи (физичка перцепција, физиолошка стања, физиолошке реакције, жеље, мишљење и говор) ${ }^{2}$ у мањој или већој мери уткани у овај систем. ${ }^{3}$ Рађајући се у средишту човековог бића, у души односно срцу, ${ }^{4}$ емоције представљају његову реакцију на дешавања у свету који га окружује. Мисаона активност, односно процена важности дешавања претходи свакој емоционалној реакцији, ${ }^{5}$ па стога менталност представља један од кључних елемената у језичкој концептуализацији емоција. ${ }^{6}$ Уз то, називи за емоције (вера, нада, льубав, страх итд.) творе велики број прецедентних текстова ${ }^{7}$ у оквиру мотивационог нивоа језичке личности, па се могу посматрати као митологеме.

5. Али пре него што се позабавимо утврђивањем релевантних обележја које љубав поседује као реч, концепт и митологема у одабраном материјалу, навешћемо неколико напомена терминолошко-појмовног карактера.

Како се термини реч, концепт и митологема у различитим а каткада и у истим лексиколошким школама различито поимају, морамо прецизирати коју вредност они имају у овом нашем истраживању. У руској лексиколошкој школи данас опште је прихваћено мишљење по коме се реч сматра основном лексичком јединицом ${ }^{8}$. Ово схватање разликује се од оног који негује српска лексикологија где се „реч као јединица лексичког система назива лексемом” (Гортан-Премк 1997: 36). Термин лексема се, међутим, на овакав начин у руској лексикологији користио у првим фазама њеног формирања (у делима В. В. Виноградова и његових следбеника). Опозиција нереализована/реализована лексичка јединица одражена у терминима реч/лексема, у истраживањима из сфере лексичке семантике, потиснута је данас у други план, док се тежиште помера на опозицију

2 Видети о томе у студији Апресјан 1995: 355-356.

3 Анализа смисаоних садржаја речи којима се означавају емоције постала је могућа тек онда када су у истраживање уведени когнитивни параметри, тј. када су оне почеле да се посматрају као сложене концептуалне структуре. Видети о томе у књизи Шмељов 1977: 57.

4 По Апресјану све емоције имају као заједнички семантички примитив глагол осећати. (Апресјан 1995: 356)

5 Видети о томе у студији Миливојевић 2000: 14.

6 Видети о томе у раду Радић-Дугоњић 2003: 323.

7 Видети о томе у књизи Караулов 1987: 216.

8 Видети о томе у књизи Белошапкова 1989: 180. 
лексема/семема. Наиме, у руској лексикологији се данас издвајају две јединице лексичког система: реч, као основна лексичка јединица, и лексичко-семантичка варијанта, као елементарна лексичка јединица. Ова друга означава се абревијатуром ЛСВ. Реч се, према томе, састоји од једне или више лексичко-семантичких варијанти, тј. представља надскуп у односу на ЛСВ. Обе јединице, и основна и елементарна, одликују се двопланском природом тј. формалним и семантичким обележјима. ЛСВ се дефинише као укупност свих граматичких облика, обједињених одређеним лексичким значењем. За означавање плана израза речи и ЛСВ користи се термин лексема, док се за означавање плана садржаја користи термин семема. Лексема је, према томе, знак у свом графијском и аудитивном лику, док је семема елементарно значење које има комуникативни, социјални карактер. Стога речници бележе семеме као значења речи. Лексему чини укупност свих конкретних реализација у тексту тзв. лекса, док укупност свих семема формира значење. ${ }^{9}$ У истраживањима когнитивне оријентације у русистици се термин реч (слово) односи и на јединицу унутрашњег говора, тј. језика мисли. ${ }^{10}$

Термин концепт у нашем раду употребљавамо за именовање јединица од којих се формира језичка слика света ${ }^{11}$. Аналогно овом замишљеном хипотетичком конструкту, концепти представљају отворене структуре. Појам концепта одговара представи о оним смисловима, којима се служи човек у процесу мишљења, а који одражавају садржај искуства и знања, садржај резултата целокупне човекове активности и процеса спознаје света у виду фрагмената знања. То су подаци о ономе што јединка зна, претпоставља, мисли, замишља о објектима у свету. Све ове информације које карактеришу концепт појављују се „на површини”, у вербализованом виду, у оквиру синтаксичких и асоцијативним путем формираних структура. ${ }^{12}$ Овако појмовно схватање термина концепт пре свега се односи на тзв. концепт имена, који се првенствено примењују у истраживању језичких садржаја. Особености концепта у књижевном делу састоје се у томе, што се његови елементи утврђују у оквиру

9 Види о томе у књизи Белошапкова 1989: 182-183.

10 Ове јединице не одликује детерминизам везе ознаке и означенога, знаковна природа ове везе, нити су оне носиоци значења. Оне се одликују дисперзијом значења до смисла, симболичном функцијом, координираношћу с јединицама тезауруса личности. Видети о томе у књизи Караулов 1987: 206.

11 Видети о томе у раду Радић-Дугоњић 2003: 322.

12 Овакво схватање елемената концепта у донекле упрошћеном виду, изнето је у књизи Ристић-Радић-Дугоњић 1999. Исцрпни преглед другачијих мишљења о елеменатима концепата могу се наћи у књизи КСКТ 1996. 
његовог семантичког поља. То значи да се они на вербално-семантичком плану укључују у хијерархијски организоване структуре, повезане хипо-хиперонимским односима.

Термином митологема обухватамо у најширем смислу јединице лингвокултурологије у којима се одражавају инваријантни елементи културе етноса изражени у језику. ${ }^{13}$ Као и за концепт и за митологему је карактеристично да се њени елементи уочавају у фразеолошком и паремиолошком слоју. ${ }^{14}$

Посебну тешкоћу при идентификовању речи, концепата и митологема, представља то, што се све оне, испољавају на синтаксичко-семантичкој равни исказа. Концепт и митологема, уз то, представљају отворене структуре, што са своје стране знатно усложњава и онако сложену анализу.

6. Као што смо рекли, љубав уз веру и наду не представља само реч, већ и концепт категоријалног ранга, али и митологему, која припада инваријантном делу језичке личности. Однос менталне и емоционалне компоненте у полисемној структури вере, наде и льубави специфичан је за сваку од њих. Једино код љьббави емоционалност стања доминира над менталношћу.

Различита обележја која карактеришу тьубав као реч, одражавају се у различитим вербализованим спојевима. Они су у системском виду представљени у дескриптивним, али и у преводним речницима активног типа, док их традиционални речници приказују само фрагментарно. Тако, на пример, преводни руско-српски речници као еквивалент руском любовь наводе српско тьубав, издвајајући на прво место ЛСВ тьубав према коме, чему (љубав према домовини) ${ }^{15}$ и, самим тим, подцртавајући истоветност ових двеју речи ${ }^{16}$ у погледу спојивости.

Погледајмо како се ови примери спојивости одражавају у транслатолошкој равни. Типови спојивости льубав према юој/любовь к ней; прва, права льубав/первая настоящая любовь представљају пример директне семантичке међујезичке еквиваленције:

(1) Сва та льубав према юој, зар није била као нека разонода те двојице? (С 1978: 87)

13 Видети о томе у књизи Маслова 2001: 38.

14 Видети о томе у студији Телија 1996: 215.

15 Видети о томе у речницима Станковић 1988, Пољанец 1974.

16 Још више поистовећују ове речи тзв. лексички минимуми, својеврсни речници који треба да омогуће активно учење језика у складу са Заједничким европским оквиром. Видети о томе у публикацији ЛМ 2002: 64. 
(1а) И разве любовь к ней не была развлечением для обоих братьев? (П 178: 86)

(2) То му је била прва, права льубав, баш кад му и отаи зажеле да га ожени. (С 1978: 116)

(2а) Это была его первая настоящая любовь, и пришла она как раз в то время, когда отеи задумал его женить. (П 1978: 110).

Генетска блискост међу словенским језицима често условљава како формалну, тако и семантичку сличност њихових речи. Различите комбинације ових двају параметара основ су на коме се заснива њихова међујезичка типологија. Један од њених поларитета на плану речи љьубав/любовь представља тип изражен предлошко-падешком везом без тьубави/ без любви у адвербијалној функцији:

(3) Пошто су их венчали сасвим изненада и без тубави, он се скоро две године понашао према юој као туђ човек (С 1978: 74).

(3а) Поженили их неожиданно, без любви, он почти два года относился к ней с учтивостью постороннего человека...(П 1978: 75).

На другој страни, међутим, налазе се типови спојева чију формалну еквивалентност на међујезичком плану прати знатна семантичка диференцираност: нпр. бити у лубави с неким/быть в любви скем-н. Они се, по правилу, бележе у дескриптивним речницима српског и руског језика, а њихово семантичко идентификовање указује на недовољну језичку компетенцију корисника. Преводиоци их сврставају у сферу „лажних пријатеља" и колико год је то могуће избегавају.

Погледајмо примере из наше грађе:

(4) После пригушеног вриска и тома, нестајали су у помрчини, а растајали су се после нежно, у вубави, испод плотова обраслих трнем, под којима је, низ брдо, жуборила вода.(С 1978: 27)

(4а) После приглушенного визга и возни, парочки скрывались в темноте, а прощзались нежно, пюбовно, под заросшими терновником изгородями, возле которых журча бежал ручеек. (П 1978: 38)

Предлошко-падешки спој у љубави (4) у функцији глаголске допуне поседује семе, пријатељство, слога ${ }^{17}$, док се у његовом преводном еквиваленту любовно (4а) истиче ЛСВ „чувство горячей сердечной склонности, влечение к лицу другого пола" ${ }^{18}$, која је доминантна и у споју быmь в любви с кем-н.

\footnotetext{
17 Видети о томе у РСАНУ 1989.

18 Видети о томе у БТС 2000.
} 
Чак и онда када се, у оригиналу и преводу не употребе формално еквивалентни спојеви, семантичка вредност превода може се наћи ван семантичког оквира задатог оригиналом. Управо такав пример представљају.

(5) Груди своје приносила му је тако близу као што се у льубави приносе образи. (С 1978: 61)

(5а) Груди свои она придвигала к нему так близко, словно губы для поцелуя. (П 1978: 65).

Изостављањем формално израженог, вербализованог еквивалента у руском преводу (5a) и супституцијом соматизма образ, соматизмом усне (2убы) у оквиру поређења, померен је семантички план превода у дијаметрално супротном правцу у односу на оригинал. Промене у вербално-семантичком нивоу превода у односу на вербално-семантички ниво оригинала у примерима (4), (4a), (5) и (5a), међутим, последица су међујезичког контакта српске и руске језичке личности на когнитивном плану, у сфери концепта тьббав ${ }^{19}$.

7. Концепт љьубав у руској језичкој слици света се као доминантним обележјем одликује опозицијом узвишено/снижено (Шмељов 2002: 170). Узвишеном регистру припада оно осећање које субјекат испољава према објекту љубави (љубав1). Оно се локализује у срцу. Сниженом регистру, пак, припада оно стање задовољства које субјекат осећа због остварења одређене ситуације (љубав2), које се, поред срца, може локализовати и у души. Љубав1 подразумева како чулну љубав, код које постоји жеља за сједињењем са објектом љубави, тако и алтруистичку љубав, код које доминира жеља да се објекту љубави учини добро. ${ }^{20}$ Наведена обележја карактеришу и концепт љьббав у српској језичкој слици света. ${ }^{21}$ Разлика на међујезичком плану између концепата љубав и любовь, међутим, запажа се у погледу улоге коју алтруистичка љубав има у склопу интегралних концепата, у односу на остале врсте љубави. ${ }^{22}$ Управо овом чињеницом

19 Кључна обележја којима се одликује поље концепта љьбав у српском језику издвојићемо на основу глагола волети, љубити, придева љубавни и именица пољубаи и загрљај. Поље концепта любовь у руском језику обухвата глаголе любить, иеловать, придев любовный и именице поцелуй и объятие.

20 Видети о томе у студији Шмељов 2002: 171.

21 О локализованости емоције изражене глаголом волети видети у Ристић-Радић-Дугоњић 1999: 170.

22 Потврду за ову тврдњу налазимо у другим когнитивним јединицама, на пример у сценарију молбе :учинити коме љубав, љубави ти, за љубав нечега, мени за тьубав, за твоју љубав, РСАНУ 1989. 
могу се објаснити релације $у$ льббави/любовно и у љубави/0 у наведеним примерима, јер се у њима сучељавају алтруистичка љубав ( $у$ тубави) и чулна љубав (любовно).

8. Познато је да се у руској језичкој слици света љубављу именује један од најизразитијих културних концепата (Апресјан 2000: 180). Погледајмо нека његова обележја у вези са тзв. чулном љубављу.

Према дефиницији коју јој даје Апресјан, означивши је као любовь 1.1., чулна љубав као основна животворна сила представља позитивно осећање, али и релацију између субјекта и објекта. Концепт идеалне љубави, настао на основу руског фразеолошког блага, као и прозних и поетских дела лепе књижевности, подразумева изузетно јако и дубоко осећање, углавном необјашњиво и драматично, које се осећа једном у животу према јединственом човеку супротног пола. Субјекат љубави верује да у свету нема другог човека који би волео објекат љубави тако јако као што га он воли. Повезано са физичком блискошћу ово осећање-релација углавном бива узајамно, узвишено а човеку даје осећај среће.

Ако применимо исте параметре при издвајању обележја концепта чулна тьбав у српском језику, запазићемо много заједничких елемената с руским концептом. И у српском језику чулна љуббав подразумева интензивно и дубоко осећање, усмерено према издвојеном из мноштва, јединственом бићу супротног пола. У српској језичкој личности концепт льббав, међутим, одликује се изразитијом амбивалентношћу (mопла, чиста, страсна, блиста од тьубави, тубавни занос према луда тьубав, мора од туббави, льубав му памет попила, зацопати се, имакати се итд.), особеном персонифицираношћу (водити, проводити тьббав), посебном повезаношћу са другим концептима-емоцијама (нпр. тьубав-срећа) итд.

Будући да љубав у руској језичкој слици света представља један од најузвишенијих културних концепата, за руску језичку личност није карактеристично да се облици испољавања љубави излажу презиру и погрдама. Овим се може објаснити ширење поља концепта садржано у руском преводу :

(6) Псовао је тене загрльаје и пољупие. (С 1978:12)

(6а) ...мысленно посылая ко всем чертям эти ее объятия и поцелуи. (П 1978:25).

На амбивалентну природу српског концепта тьубав, која се у погледу смисла креће у интервалу од крајње узвишеног до крајње сниженог, указује и присуство експресивног синонимског низа у вези са глаголом тьбити се - имакати се, туббакати се итд. За разлику од њега, руско целоваться поседује искључиво експресивне синониме узвишеног реги- 
стра лобзаться, лобызаться ${ }^{23}$. Зато се експресивност која карактерише српски глагол измакати се, не исказује у преводу руским експресивним еквивалентом, већ се преноси на метафоричку слику другог елемента у исказу:

(7) То није била она рано удата висока девојка, ни она дивна млада са главом своје ћерчице на дојии, ни она пуна, грудата жена, коју је чуо кроз зид како се целу ноћ имаче и како мумла. (С 1978: 57)

(7а) Это была уже не та, рано вышедшая замуж статная девуш$\kappa a$, и не чудесная молодая мать с дочкой у груди, и не полная, грудастая баба, что иельми ночами иелуется и воркует за стеной. (П 1978: 62)

9. Дуална природа емоције льубав представља једно од њених кључних концептуалних обележја. ${ }^{24}$ Она је посебно истакнута у оквиру чулне љьубави кроз две хипостазије - волети и бити вољен. У концепту љьубав у „Сеобама“ Милоша Црњанског највећи број гешталт-структура, сценарија и фрејмова управо припада сфери чулне љубави, док телесност представља основно обележје његових књижевних јунака. ${ }^{25}$ Али у концепту елемент поседовања нема доминантну улогу. Наместо поседовања у први план истакнута је жудња за љубављу, жудња да се буде вољен. Она је најјасније изражена у сцени Дафининог умирања, кроз поетско сучељавање Ероса и Танатоса. Ову митску сцену финализује исказ:

(8) Била је и тада још жељна лубави. (С 1978: 183)

(8а) Даже в ту минуту ей хотелось любви. (П 1978: 163).

Спој жељна љьубави јасно указује на то да је овде реч о љубави примања и давања, а не љубави поседовања. Руски еквивалент ей хотелось любви, пак, концепт љубав доводи у везу са концептом жеља, код кога се доминантно обележје истиче управо поседовање. ${ }^{26}$

10. Поље српског концепта љубав, у значењу чулне љубави, обухвата два смисаоно еквиполентна глагола - неутрално волети и стилски маркирано љуббти. У „Сеобама” се ови глаголи не употребљавају у функцији синонима, већ се глагол љьубити дислоцира на периферију поља

23 Видети о томе у речнику Јевгењевна 1975.

24 „Осећање љубави је пријатно осећање које субјекат осећа према оном објекту који доживљава изузетно вредним и који сматра саставним делом свог интимног света.” Миливојевић 2000: 560.

25 Видети о томе у студији Петковић 1988: 289.

26 Видети о томе глагол хотеться у речнику Апресјан 2000: 392. 
концепта (у руском концепту његов еквивалент представља глагол целовать). Па ипак, у односу на све остале елементе поља концепта, глагол љуббити у језику романа најчешће је присутан. За наше истраживање он је значајан и због тога што указује на обележја льубави као митологеме. Погледајмо следеће примере:

(9) Заситивши се, последюих дана, пред полазак, у општем плачу и кукану, својих жена, при оном метежу и мукама до миле волье их љубећи и тукући, они сада нису ишли да траже жене. (C 1978: 25).

(9а) В последние перед выступлением дни они всласть насытились своими женами, иелуя и колотя их среди общего переполоха, плача и причитаний, и теперь шли вовсе не в поисках женщин. (П 1978: 37).

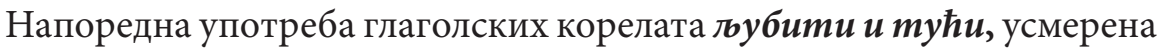
према истом објекту жена тешко да може бити разумљива носиоцу друге, чак и блиске културе. Оваква обележја језичке личности оригинала у преводу, по правилу, остају непреводива. Уз то, треба напоменути да тек из перспективе превода, у наведеним примерима постају уочљивије културолошке специфичности оригинала у сфери родбинске терминологије (жена / жена, женщина).

Глагол тубити појављује се у исказима повезаним са сваким од три средишња лика у роману. Објекти према којима је усмерена њихова љубав, као и начини њеног тактилног изражавања указују на инваријантне елементе, који су дубоко укорењени у култури етноса (иако прељубница, Дафина льуби мужа, Вук льуби децу итд.). Откривањем оваквих елемената, међутим, нашли бисмо се ван методолошког оквира наше анализе.

\section{ЛИТЕРАТУРА}

РСАНУ 1989: Речник српскохрватског књижевног и народног језика. - Београд. - књ. XIV.

Апресјан 1995: Апресян, Ю. Д. Интегральное описание языка и системная лексикография, Избранные труды. - Москва. - Том 2. - 766 С.

Апресјан 2000: Апресян, Ю. Д. Новый объяснительный словарь синонимов русского языка. - Москва. - Том 2.

Белошапкова 1989: Белошапкова, В. А. Современный русский язык. - Москва. 
БТС 2000: Большой толковый словарь русского языка. - Санкт-Петербург. -1536 C.

Гортан-Премк 1997: Гортан-Премк, Д. Полисемија и организација лексичког система у српском језику. - Београд.

Јевгењевна 1975: Евгеньевна, А. П. Словарь синонимов. - Москва.

Караулов 1987: Караулов, Ю.Н. Русский язык и языковая личность. - Москва. - 262 С.

КСКТ 1996: Кубрякова, Е. С. Краткий словарь когнитивных терминов. - Москва. - 245 С.

ЛМ 2002: Лексический минимум по русскому языку как иностранному. Москва, Санкт Петербург.

Маслова 2001: Маслова, В. А. Лингвокультурология. - Москва.

Миливојевић 2000: Milivojević, Z. Emocije. - Novi Sad. - 672 S.

П 1978: Црнянский, М. Переселение.(перевод с сербскохорватского И. Дорбы). -Москва. - кн. 1. - 220 С.

Петковић 1988: Петковић, Н. Сан Вука Исаковича (О песничкој структури „Сеоба”). - Београд.

Пољанец 1973: Poljanec, R. F., Madatova-Poljanec, S. M. Rusko-hrvatski rječnik. - Zagreb.

Радић-Дугоњић 2003: Радић-Дугоњић, М. Прилог проучавању инваријантних и варијантних обележја концепата емоција у српском и руском језику (на материјалу романа „Сеобе” М. Црњанског и његовог руског превода), Стил, бр. 3.

Ристић-Радић-Дугоњић 1999: Ристић, С., Радић-Дугоњић, М. Реч. Смисао. Сазнање. - Београд,

С 1978: Црњански, М. Сеобе. - Београд. - књ. 1. - 251 С.

Станковић 1988: Станковић, Б. Руско-српскохрватски речник. - Нови Сад, Москва.

Телија 1996: Телия, В. Н. Русская фразеология. - Москва.

Шмељов 1977: Шмелев, Д. Н. Современный русский язык. Лексика. - Москва.

Шмељов 2002: Шмелев, А. Д. Русская языковая модель мира. - Москва. 
ЛЮБОВЬ - СЛОВО, КОНЦЕПТ, МИФОЛОГЕМА (НА МАТЕРИАЛЕ РОМАНА „СЕОБЕ“ МИЛОША ЦРНЯНСКОГО И ЕГО ПЕРЕВОДА НА РУССКИЙ ЯЗЫК)

Резюме

Предметом настоящей статьи является любовь, как сложная транслатологическая единица. Исходя из теории языковой личности, автор пытается обнаружить ее свойства как слова (единицы нулевого личностного уровня), концепта (единицы когнитивного уровня) и мифологемы (единицы мотивационного уровня), играющие ключевую роль в языке художественного произведения и его перевода на близкородственный славянский язык. 